\title{
GREEN ENERGY - UTILIZATION AND BARRIERS OF SOLAR AND HYDRO POWER TECHNOLOGIES
}

\section{SNEHITA KILARI, P. ANANTHA LAKSHMI \& PALLAVI UPPALA}

Assistant Professor, R.V.R.\& J.C.C.E, Guntur, Andhra Pradesh, India

\begin{abstract}
Conventional energy sources, the best functional drivers of economic development essentially depend on oil, coal, and natural gas. Though these conventional energy sources noticeably effect the escalation of economic progress, simultaneously they are proven to be more hazardous to the environment and human health. The alternative sources of energy like solar, wind, hydro, biomass, geothermal \& others may not have a specific impact on climatic conditions. These Green energy sources capably meet $12 \%$ of the world's demand for energy. These highly resourceful green energy sources are initiated and advanced at present in the form of Green technology which is often referred to as eco-friendly clean technology. It is an emerging technology in fulfilling the requisites of future generation, without diminishing or damaging natural resources available on the earth. It employs pioneering techniques in sustainable development to create eco-friendly products. The inherent reason for considering the Green technology the best of all ecological approaches relies in its capability to impact humans in diverse areas for ex., environment, economic, and social. This paper presents extensive perspective of Solar and Hydro sources for Green technology, its challenges and opportunities in line with global endeavors and trends towards sustainable development. It also outlined broad spectrum of areas where Green technologies are emerging. It is assumed that the progress of Green technology will initiate global, sustainable and macro-economic powers that have an impact on societies, economies and a way of life in future.

KEYWORDS: Green Energy, Renewable Energy, Solar, Hydro, Global \& Green Technology
\end{abstract}

Received: Jun 06, 2020; Accepted: Jun 26, 2020; Published: Jun 30, 2020; Paper Id.: IJMPERDJUN2020151

\section{INTRODUCTION}

Over past two decades, alarming effects of greenhouse gas emissions \& hike in fossil fuel prices aroused interest in the environmental issues. The cheapest methods to decarbonize the energy supply of the world, has become the most controversial topic as it challenges the need to acknowledge the development of alternative energy resources [1]. The alternative sources of energy like solar, wind, hydro, biomass, geothermal, tidal \& others do not directly influence the environment. These naturally replenished resources are often termed as Green energy sources which are being extracted, produced and consumed.

All over the world Green energy exploits, easily available energy sources in rural and inaccessible areas that don't have access to electricity. Progressions in Green energy technologies have minimized the cost of solar panels, wind turbines and other green energy sources [2]. Hence the ability to produce electricity is transferred from coal, oil, gas and utility companies to common public. The figure1 illustrates paths of various forms of green energy from source to service. This paper concentrates more on utilization, technologies and barriers in the way of electricity production using the three major green energy sources- solar, hydel and geothermal. 


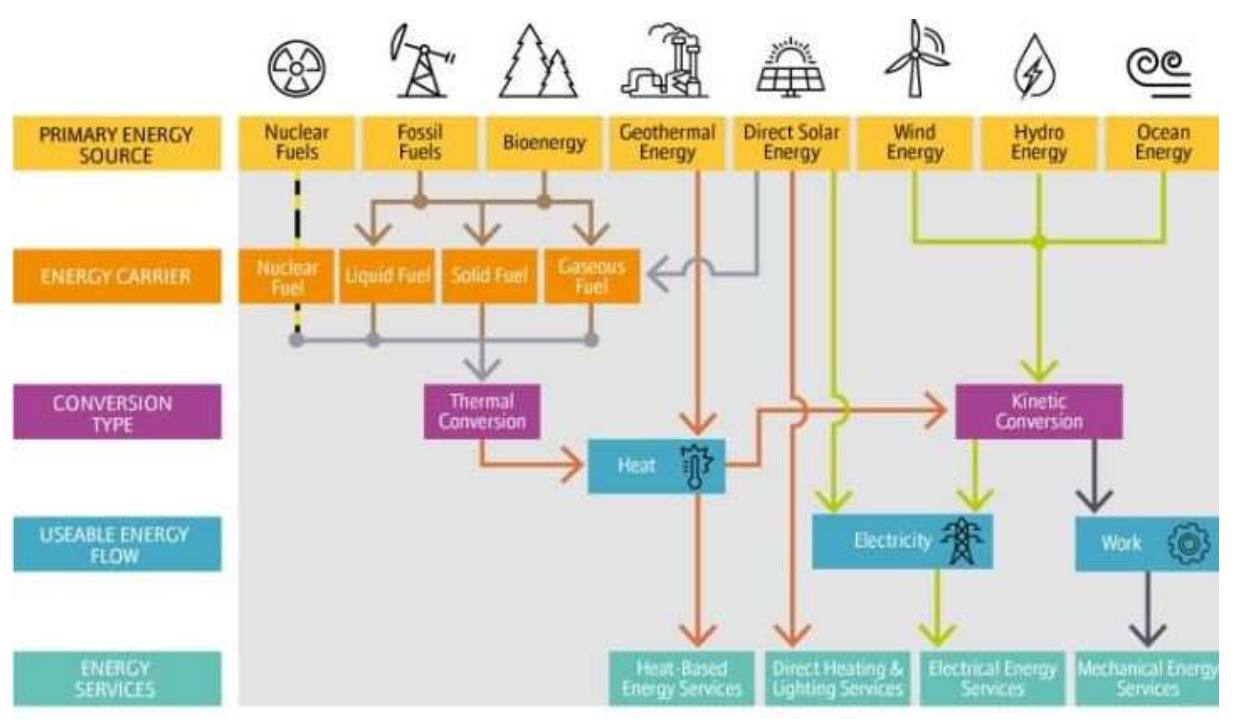

Figure 1: Paths of Energy from Source to Service.

\section{SOLAR ENERGY}

Among several resources of green energy solar energy stands supreme in driving the earth. This energy totally depends on nuclear fusion from the core of the Sun. It epitomizes infinite supply of energy based on the longevity of sun and mankind. Though one billionth of total solar energy is reaching the earth's surface that is enough to fulfil the world's energy requirements. Figure 2 shows solar photovoltaic power plant of capacity 100MW at Village Hardani \& Nadiyan Kalan, Baori Tehsil, Jodhpur, and Rajasthan - a solar power plant. Many hardships occur in harnessing the energy. Various methods are developed to collect and convert this solar energy into electricity such as photovoltaic cells. A few current applications of solar energy include solar cookers, solar vehicles, solar water heating, solar heating of buildings, solar distillation, solar pumping, Solar drying of agricultural products, solar furnaces, solar electric power generation etc. [3]

\subsection{Utilization}

Major obstacle faced by solar energy dependent systems is lack of continuous course of sunlight. Among South Asian countries, India with extreme temperatures has vast solar energy potential. Due to its abundance, India's electricity demands are being successfully fulfilled by a small portion of the full incident solar energy. Across India the incidence of Solar energy is approximately 5,000 trillion $\mathrm{kWh}$ per year and $4-7 \mathrm{kWh} / \mathrm{sq} . \mathrm{m}$ per day. To maximize the effect of this incident energy, organizational and domestic structures should be modelled accordingly.

By the end of June 2019, India succeeded to enhance $3.5 \mathrm{GW}$ of grid-connected solar power capacity. This is a peripheral increase from the $3 \mathrm{GW}$ capacity added in H2 2018, but considerably lesser than the all-time high of $6 \mathrm{GW}$ added in H1 2018. As India entered into the solar game in 2011 it is forecast that it would be able to achieve massive production by 2025. Solar boom has just commenced and with the present government's target to increase the installed capacity from $57.4 \mathrm{GW}$ to $100 \mathrm{GW}$ by 2022 . Electricity plays a crucial role in the development of economy, industrialization, urbanization, for an enriched life in society. India, at present is concentrating on Solar Thermal Electricity (STE) generating systems that are emerging green energy technologies, practical options to generate electricity in future. Though solar energy is free of cost, the 
expenditure to purchase, install and maintain the equipment is high. The figure 3 illustrates the cumulative capacity of solar power over the past years in Mega Watts. By 2019 the value reaches to 28,181 MW.

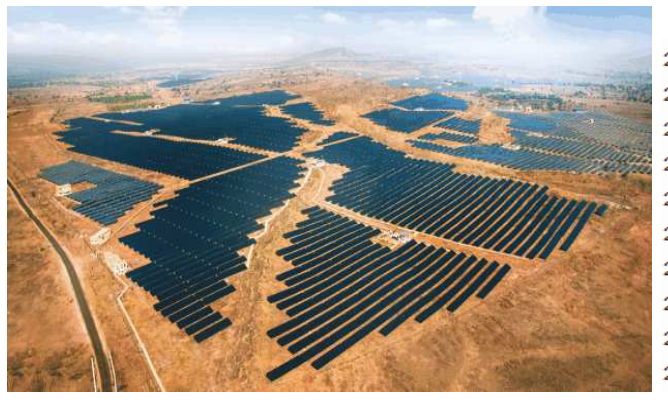

Figure 2: Solar Power Plant-Rajasthan.

\begin{tabular}{|c|c|}
\hline 2010 & 161 \\
\hline 2011 & 461 \\
\hline 0012 & 1,205 \\
\hline 13 & 2,319 \\
\hline 014 & 2,632 \\
\hline 15 & 3,744 \\
\hline 16 & 6,763 \\
\hline 17 & 12,289 \\
\hline & 21,651 \\
\hline & 28,18 \\
\hline
\end{tabular}

Figure 3: Cumulative Capacity in MW.

\section{HYDRO ENERGY}

The history of hydel/water energy is as ancient as history of human civilization. Ancient Egyptians are considered to be the prime people to utilize water as the best alternative energy source. Water energy is created from the power of moving water. Among all the natural resources hydel energy positions next to wind and solar energies. Figure 4 illustrates a hydro project with water being released from dam. Across the world, Hydel power is currently one of the largest green energy sources for generation of power [4, 5]. Advancements of Hydro power generation have had a robust growth in the past 50 years.

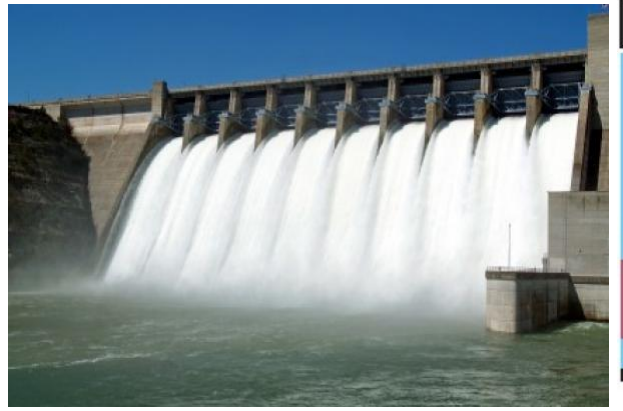

Figure 4: Hydro Project in India.

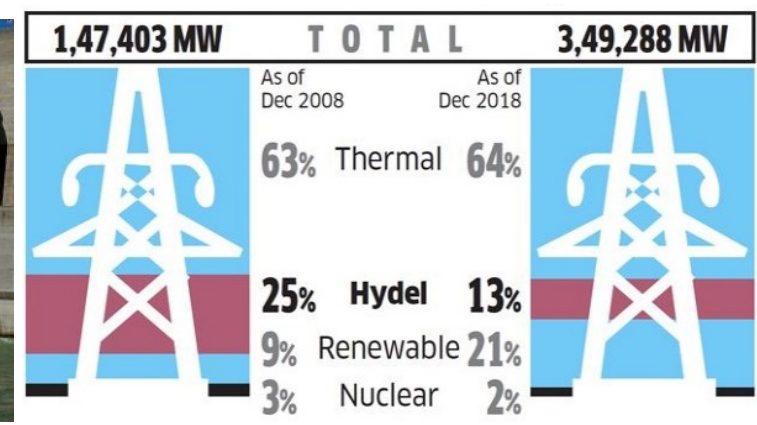

Figure 5: \% of Total Installed Capacity.

\subsection{Utilization}

The energy of flowing water is utilized to generate hydroelectric power to guide the turbines towards the production of electricity. India remained in the 7 th position as the largest producer of hydroelectric power in the world with a total capacity of 47,057 MW. Maximum hydroelectric power is being produced by dams constructed across large-flow Rivers. India is gifted with heavy flow rivers like Bhagirathi, Krishna, Narmada, Baspa, Satluj, Beas, Ravi, Chenab etc. whose capacity is shown in below table 1. A water reservoir supporting a dam represents stored potential energy. The flow of water through the penstock which drives the turbines is transformed to kinetic energy and later to electricity. Like other green energy sources hydroelectric power is the best in long term as it's clean and cheap bearing the early construction costs.

The scenario of hydroelectric power over past two decades was characterized to be the best alternative green energy source to coal and gas centered electricity production in India. From 2000s the government was eager to establish hydel power plants which enthused many private sectors into action. Though wind and solar 
energies procured much attention hydel energy fortified its way fastening India in 7th position by the end of 2018 with a total of 47,057 MW of hydroelectric power production. The figure5 illustrates that India's percentage of total installed electricity capacity has been reduced to half from $25 \%$ to $13 \%$ where in there is not much difference in thermal and nuclear power. Surrounded by troubles to procure land, financial crisis due to the uncertainties in time for completing the projects and changes in the government sectors makes the production of electricity questionable by hydel sector in forth coming years[6].

Table 1: Major Hydro PowerPlants in India with Capacity More Than 1000 MW

\begin{tabular}{|l|l|l|c|}
\hline \multicolumn{1}{|c|}{ Dam } & \multicolumn{1}{c|}{ River } & \multicolumn{1}{c|}{ Location } & Capacity (MW) \\
\hline Tehri Dam & Bhagirathi & Uttarakhand & $2400 \mathrm{MW}$ \\
\hline Srisailam Dam & Krishna & Andhra Pradesh & $1670 \mathrm{MW}$ \\
\hline Sardar Sarovar & Narmada & Gujarat & $1450 \mathrm{MW}$ \\
\hline Nathpa Jhakri & Satluj & Himachal Pradesh & $1500 \mathrm{MW}$ \\
\hline Bhakra Dam & Satluj & Punjab & $1325 \mathrm{MW}$ \\
\hline Sharavathi & Sharavati & Karnataka & $1035 \mathrm{MW}$ \\
\hline Indira Sagar & Narmada & Madhya Pradesh & $1000 \mathrm{MW}$ \\
\hline Koyna & Koyna & Maharashtra & $1960 \mathrm{MW}$ \\
\hline
\end{tabular}

Thought the hydropower is renewable, it's environmental and social impacts like displacement of many people, methane emissions from rotting vegetation in reservoirs, detrimental effects on biodiversity because of large dams becoming a precursor of big hydel projects. In 2015, the Indian government stopped categorizing hydel projects larger than $25 \mathrm{MW}$ as renewable. India has 4,500 MW of hydel projects with a capacity of less than $25 \mathrm{MW}$ each [7]. The government has assessed the country's hydro power potential (more than $25 \mathrm{MW}$ ) at over 1, 45,000 MW. Government of India at the end of twelfth five year plan decided to revise the target to achieve renewable power to $175 \mathrm{GW}$ by 2022 .

\section{TECHNOLOGICAL DEVELOPMENTS}

Now a days Rigorous technological developments have placed the industry for huge growth [3].To advance the efficiency and cost effectiveness of solar cells much research has been carried on from a decade. The energy grasped from sun light is utilized and being transformed into electricity only by $15 \%$ by the solar cell whereas maximum of $85 \%$ of energy is becoming a waste. There always exists a dire need for new technology which is capable to enhance the capturing of sun light and conversion.

\subsection{Advances in Energy Storage}

Scientists concentrate more on new methods and technologies to store energy produced by solar PV systems. Among many methods the foremost is Solar panel with Built-In battery. The key feature of this built-in battery is that it does not operate as two standalone systems but it is built in with rechargeable battery in the solar panel. Solar and hybrid vehicles are significantly highlighted in a very recent India Auto Expo. The significant task in the success of this electric mobility possible is the cost effective built in energy storage systems. Figure 6 shows the automobiles having solar panels. According to recent statistical analysis by IRENA there is an optimal amount of cost reduction by 80\% for lining up solar PV projects in India between 2010 and 2018.

\subsection{Advances in Solar Cell Manufacturing}

The manufacturing processes of solar PV technologies are playing vital role in their availability at low cost. So for 
this reason continuous research has been conducted to enhance the efficiency of manufacturing solar components.

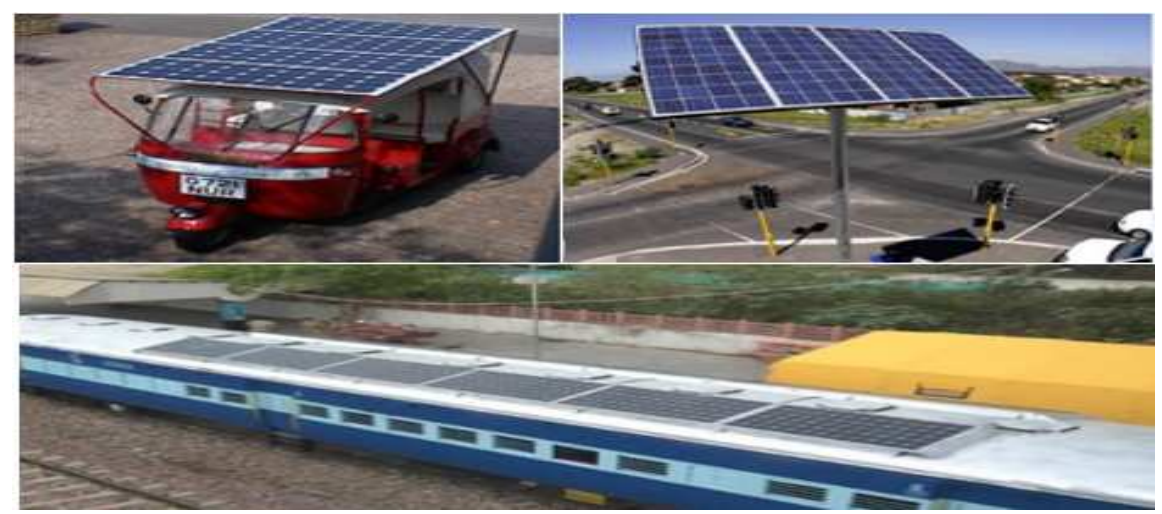

Figure 6: Solar Energy Storage Applications.

\subsection{Advances in Solar Applications}

Now a days solar applications have transformed their appearance. Earlier they were fixed at roof tops or mounted for industrial purposes. As a result of indigenous innovations in this field solar road ways came into existence. Government is very stern and decisive to construct highways and roads with solar panels to minimize the usage of electricity. Solar powered traffic signals, street lights are being implemented at various places on experimental basis and are capable to function during power failure. Many subsidies and electricity grid incentives are granted by the Government of India and Jawaharlal Nehru National Solar Mission (JNNSM) since 2010. It is being influential in adopting solar energy and aimed to reach $20 \mathrm{GW}$ solar power overcoming $9500 \mathrm{MW}$ present installed capacity.

\section{BARRIERS}

Though solar and hydro power immensely contributes to energy generation they face obstacles in their progression because of higher initial cost for fixing and also for environmental and population relocation [4]. The availability of funding, political and market risks, resource allocation priorities and local environmental concerns are considered to be few barriers to the development and utilization of solar hydro power technologies. The barriers in the way of using these green energy sources includes the following:

\subsection{Political and Regulatory Barriers}

Inadequate policies and regulations is a major hindrance to the development and adoption of these Green energy technologies. To enhance the interest of investors lucid legal policies and procedures are to be adopted by the government sector. Private sector which is the major driving force for country's economy is highly effected by these in adequate policies and authorization procedures in implementing the Green energy projects.

\subsection{Technical Barriers}

The major barrier encountered by India is obsolete technology and lack of infrastructure in the way of Green technology development. In addition to these lack of physical facilities like trained labor, modern equipment, service and maintenance, scarcity of indigenous spare parts and equipment failure are other challenges in hindering the Green energy utilization. 


\subsection{Social-Cultural Barriers}

Lack of awareness, illiteracy and knowledge about the utility of Green energy technologies among the rural communities and households is the major problem faced by the manufacturers of Green technologies.

\subsection{Financial and Economic Barriers}

Due to high initial investment in Green energy technologies many investors consider it to be a major obstacle which is augmented by transaction costs, financial status, of the investors and lack of clarity in the incentives and subsidies announced by the government.

\subsection{Market-Related Barriers}

The initial market price of these technologies remain high, unavailability, and lack of appropriate and less competitive green energy models a consumers finds it difficult to consider use these technologies.

\subsection{Geographical and Ecological Barriers}

The geographical location functions as a major driving force in the accumulation of natural resources. As human population is inversely related to the availability of green energy resources scarcity occurs and therefore they become too expensive and unaffordable to consumers.

\section{CONCLUSIONS}

In this paper, we attempted to explain the utilization of solar, hydro sources and barriers of these technologies due to their noteworthy impact to power generation by green sources. At universal level there is a continuous increase of renewable energy production and supply. An enormous amount was invested on green energy sources over the recent years. Utmost significance has been laid on the development costs, current production capacity and the estimated capacity. Both solar and hydro technologies have several merits and demerits that differ in various perspectives. This variation or differentiation occurs in the availability of the resources in particular locations. Besides financial limitations/restrictions the availability of advanced knowledge and technology of producers and environmental considerations also influences the applications of these technologies. The production of coalesced energy at the minimum cost is determined by different conditions to any region or part of the country. Hence there is no specific way out to every energy requirement and problem, rather an ideal solution can be selected among a set of promising renewable solutions specific to the location. The discussion above has made it clear that there are so many aspects that impede the adoption and progress of renewable energy technologies. With the progression and vigorous growth of renewable energy industry, optimistically India's future appears to be bright. Over a decade there has been a noticeable and impressive growth of the Green energy industry in India. Solar boom has just commenced and with the present government's target to increase the installed capacity from $57.4 \mathrm{GW}$ to 100 GW by 2022. The figure 7 shows tentative year wise cumulative targets of solar power to be achieved by 2022 .

Globally in the recent years, the progress in generating electricity from supplementary hydro capacities has been analogous to the mutual growth of all other renewables. Though there is an ample scope to meet the expected share of $40 \%$ in hydropower production India is forced to confine itself to 7 th position due to some technical, social and environmental aspects. As a competitor to occupy a prominent position India needs to move ahead on its hydropower generation with the rest of the world. It has been decided by the Government of India at 
the end of twelfth five year plan to revise the target to achieve hydel renewable power to $175 \mathrm{GW}$ by 2022 . Figure 8 shows the actual data and projected growth of hydro power in GW to be achieved by 2022 .
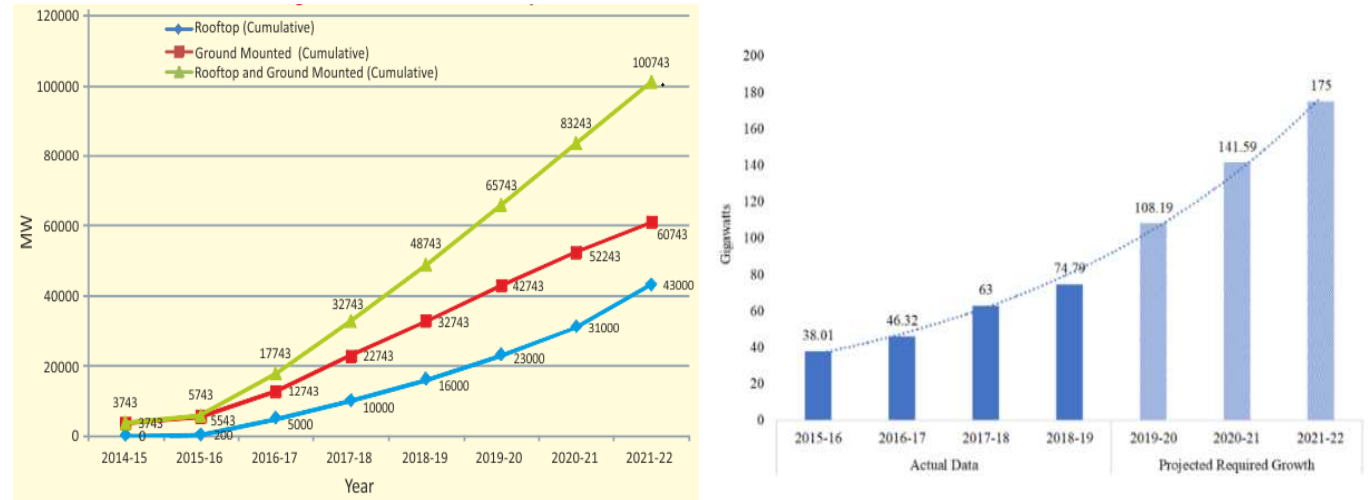

Figure 7: Year Wise Cumulative Targets of Solar Power. Figure 8. Growth of hydro power in GW

Though it is a proven fact that Green Energy sources help the sustainability of the environment other factors like political, technical, socio-cultural, financial and ecological, economical and geographical work in tandem to confine the progress and practice of green energy sources. Many developing countries find it difficult to meet high initial expenditure to establish these green energy units. Continuous research about environmental changes have made the Green Energy sources a significant element in the world energy consumption portfolio. Due to adverse and irremediable outward factors in conventional energy production, it is essential to augment and endorse renewable energy supply technologies. To reduce the unit cost of energy and to make them compatible with a challenging substitute to the conventional energy sources, escalation of power generation by means of green energy sources should be practiced.

\section{REFERENCES}

1. Sameer Saadoon Al-Juboori, (2015) Green Energy - An Introduction chapter in Opportunities and Challenges, Energy Science \& Technology.

2. Farooqi, Awais. "A Green Strategy Towards the Miscibility Studies of Styrofoam in Organic and Inorganic Solvents by Using Materials Modelling and Simulation Method." Journal of General Engineering and Technology (JGET) 1 (2016): 11-18.

3. Gyanendra singh sisodia, Pragya singh (2015) "Environmental and climate technologies" - the status of renewable energy research of India, International scientific conference.

4. Malti Goel, (2016), solar rooftop in India: Policies, challenges and outlook - Green Energy \& Environment Volume 1 , Issue 2.

5. Parmar, Jigar K., and Sunny K. Darji2\& Gajendra R. Patel. "Fuzzy Based MPPT Controller of Wind Energy Conversion System using PMSG." International Journal of Electrical and Electronics Engineering (IJEEE) 7.3: 1730.

6. Chiyembekezo S. Kaunda, Cuthbert Z. Kimambo and Torbjorn K. Nielsen, (2012) Hydropower in the Context of Sustainable Energy Supply: A Review of Technologies and Challenges ISRN Renewable Energy.

7. Joshi, Krishna. "Application of Energy Concepts for Green Buildings." International Journal of Civil, Structural, Environmental and Infrastructure Engineering Research and Development (IJCSEIERD) ISSN (P) (2016): 2249- 
6866.

8. M Gopala krishnan, (2015), Hydro Energy Sector in India: The Past, Present and Future Challenges, Proceedings of the Indian National Science Academy.

9. Ameesh Kumar Sharma, N.S. Thakur, (2016), Analyze the factors effecting the development of hydro power projects in hydro rich regions of India, Perspectives in Science.

10. Upadhyay, A. S. H. O. K. "Review of Regulatory Promotional Initiatives for Development of Renewable Energy Projects in India." Int. J. Elec. Electron. Eng. Res.(IJEEER) 4 (2014): 9-24.

11. Naveen Kumar Sharma, Prashant Kumar Tiwari, Yog Raj Sood, (2013), A comprehensive analysis of strategies, policies and development of hydropower in India: Special emphasis on small hydro power, Renewable and Sustainable Energy Reviews, Volume 18.

\section{AUTHOR PROFILES}

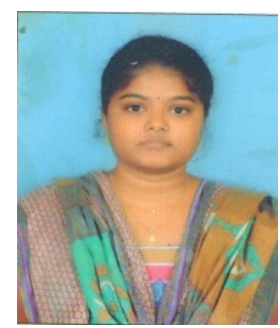

Snehita Kilari, M.Tech, Assistant Professor, Department of Mechanical Engineering, R.V.R \& J.C College of Engineering.

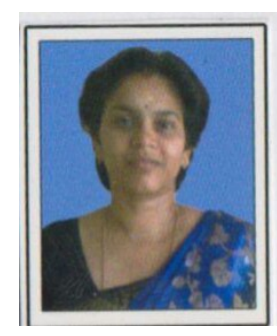

Dr. P.Anantha Lakshmi, Assistant Professor, Department of Science \& Humanities, R.V.R \& J.C College of Engineering

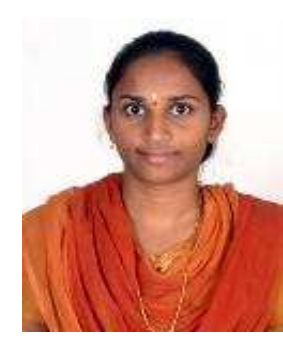

Pallavi Uppala, M.Tech, Assistant Professor, Department of Civil Engineering, R.V.R\&J.C College of Engineering 